\title{
MACPHERSON, OSSIAN AND THE BARDIC IDEAL SOME IRISH REFLECTIONS ON A GERMAN PHENOMENON
}

\author{
HARRY WHITE \\ University College Dublin
}

Izvleček: Kljub velikemu vplivu zbirke Ossianovih pesmi Jamesa Macphersona na oblikovanje nemške romantike (preko del Herderja in Goetheja) doslej vprašanje, v kolikšni meri sta obstajali poezija bardov (nem. Bardendichtung) ter zavest o škotskih in irskih melodijah $v$ nemški glasbeni misli neodvisno, še ni bilo dovolj obravnavano. Ne glede na Beethovnova srečanja z irsko tradicionalno glasbo je bolj kot sama glasba večino nemških skladateljev po Beethovnu navdihnil ideal »ljudske glasbe«.

Ključne besede: Macpherson, Ossian, Beethoven, Moore, »ljudska glasba«.

\begin{abstract}
Despite the immense influence of James Macpherson's Ossian poems on the formation of German romanticism (through the agency of Herder and Goethe), the extent to which Bardendichtung and an awareness of Scottish and Irish melodies existed independently in the German musical imagination has been insufficiently addressed. Notwithstanding Beethoven's encounter with Irish traditional music, it was the ideal of "folk music" - an imaginary construct - rather than the music itself which inspired the work of most German composers after Beethoven.
\end{abstract}

Keywords: Macpherson, Ossian, Beethoven, Moore, "folk music".

In a letter of 25 August, 1829 to his sister Fanny Hensel, Felix Mendelssohn commented on the musical impressions he received during his tour of Scotland and Wales:

No national music for me! Ten thousand devils take all folkishness! A harper in the hall of every reputed inn playing incessantly so-called folk melodies; that is: infamous, vulgar, out-of-tune trash, with a hurdy-gurdy going at the same time! Anyone, who, like myself, cannot endure Beethoven's national songs, should come here and listen to them bellowed out by rough, nasal voices, and accompanied with awkward, bungling fingers, and not grumble. ${ }^{1}$

It would be hard not to conclude from such an outburst that for Mendelssohn, at least, these sentiments marked the end of German enchantment with the great "other" of

1 Cited in Gelbart, The Invention of "Folk Music" and "Art Music", 248. 
folk music, an other which Mendelssohn himself axiomatically designates as "national music" in unruly contrast to the supreme condition of Kunstmusik, notwithstanding his own apotheosis of modality in such works as Fingal's Cave and the Scottish Symphony. The disillusion and contempt which characterise Mendelssohn's apprehension of peasant musical culture in this passage throw into sharp relief the romance and rapture of Germany's earlier engagement with the bardic ideal in literature and music. As Matthew Gelbart has argued, Mendelssohn's disdain is expressive of a belief not only in the superiority of German art music, but also in its universal condition. ${ }^{2}$ Indeed, the centre-periphery model of musical thought which Gelbart locates in the romantic generation of German composers (Mendelssohn and Schumann in particular) entails a drastic relegation of folk music from its idealised status as an originary and universal substratum of European art to an expression of national culture, in which the marginal or local claim inevitably defers to the universal strength of the German musical imagination. One thinks, for example, of Schumann's reception of Chopin, in which the German composer conceded the presence of a Polish "physiognomy” in Chopin's earlier works which would (for Schumann at least) happily disappear into the melting pot of the great tradition of German art music. ${ }^{3}$

In this paper, I would like to retrace the reception history of folk music as a category in German musical thought from its dizzying presence as an ideal type in Goethe and Herder to its deracinated condition as an expression of local colour in Schumann and Mendelssohn. In this enterprise, I will create an expressly Irish perspective from which to survey this reception history, if only because Ireland is entirely absent as a musical entity in Gelbart's work. ${ }^{4}$ Rather than rehearse here those compelling arguments which Gelbart brilliantly advances in respect of ideas about Scottish music and their impact on German musical thought, it seems to me preferable to address the Irish question (so to speak) in German musical affairs, given how little attention it has received to date. In the same year that Mendelssohn wrote his impressions of Scottish music, Hector Berlioz would exclaim "L'Irlande! Toujours L'Irlande!", not only on account of his infatuation with an Irish actress, Harriet Smithson, but more pertinently because he was reading the poems of Thomas Moore and absorbing them into his own conception of French song. ${ }^{5}$ In France, no less than in Germany, the presence and influence of Irish literature would abide at exactly the same time as the influence of Scottish music went into decline. Why should it be the case that "the Bard of Erin", as Moore was known throughout Europe, should successfully perpetuate a Celticism closely related to (but not derived from) the Ossianic lays of James McPherson at the same historical moment which witnessed the abeyance of Scottish music? ${ }^{6}$ In what

2 Gelbart remarks that in such passages Mendelssohn "had come to use 'national music' (and even 'folk' in this particular context) as inherently local and coarse, directly opposed to the absolute art music history he cared so much about". See Gelbart, The Invention of "Folk" Music, 248.

3 See Robert Schumann, Gesammelte Schriften über Musik und Musiker, ed. H. Simon, Leipzig, 1888, vol. 1:188, cited in Dahlhaus, Between Romanticism and Modernism, 84.

4 See Harry White, review of Gelbart, The Invention of "Folk" Music, 75-77.

5 For an account of Berlioz's engagement with Moore, see Rushton, "Berlioz and Irlande: from Romance to Mélodie", 224-240.

6 On the decline of Scottish music as an ideal type in German culture, see Gelbart, The Invention of "Folk" Music, 239-245. 
sense did the bardic ideal survive in the formation of German musical consciousness? And given the literary nature of Bardendichtung, might we be allowed to agree with Keats that "heard melodies are sweet, but those unheard are sweeter?" I cannot hope to answer such questions comprehensively, but they underlie the argument I should like to make in this brief paper. There are three components to this argument which I nominate here as follows: (1) the linguistic sovereignty of Irish culture in relation to the bardic ideal (2) the musical sovereignty of German culture in relation to Bardendichtung and (3) the nature of Beethoven's Irish musical experience.

\section{The linguistic sovereignty of Irish culture and the Bardic ideal}

Almost from the moment of their first appearance in the early 1760s, the Ossianic poems published by James Macpherson in Edinburgh stimulated a degree of censure and scepticism in England and Ireland which contrasts sharply with their enthusiastic reception in Germany (principally through the translations of Michael Denis). For Irish antiquarians (in particular Charles O'Conor), the romantic stimulus of Macpherson's “translations" was as nothing when set against their perceived, historical falsehood and their subversion of Gaelic culture, not least because Macpherson was regarded as having usurped the Fenian cycles of Gaelic Ireland in favour of his own construction of ancient Scottish civilization. ${ }^{8}$ But not even Macpherson could suppress the fact that Ossian was a Scottish variant of the Irish Oisín, or that Fingal was a Scots-Gaelic version of Fionn, even if he sought to promote the spurious notion that Scots-Gaelic literature was "purer" and "older" than its Irish counterpart. Such discriminations need not delay us here (and they certainly counted for nothing in the formation of European literary romanticism, in which "Ossian" and "Scotland", thanks to the genius of Johann Gottfried Herder, prevailed over "Fionn" and "Ireland"). ${ }^{9}$ There was one exception to this: the disputes over the Macpherson forgeries at home reveal an English impatience with Celticism and an Irish struggle for national

7 The line is from John Keats's “Ode on a Grecian Urn” (1819).

8 Charles O'Conor (1710-1791) was an Irish historian and antiquarian whose Dissertations on the ancient history of Ireland, to which is subjoined a dissertation on the Irish colonies established in Britain, with some remarks on Mr Mac Pherson's [sic] translation of Fingal and Temora was published in Dublin in 1766. O'Conor repudiated the Scottish origins of Macpherson's "translations" by means of proving their derivation from Irish legend and ancient literature. In this respect at least, O'Conor was of the same party as Samuel Johnson and other English critics who disputed the authenticity of Macpherson's work. See Ó Gallchoir, "Celtic Ireland and Celtic Scotland: Ossianism and The Wild Irish Girl", 114-130.

9 In this connection, it may not be irrelevant to remark that in German usage, "Scottish" and "Irish" appear to have been at least occasionally employed as synonymous designations long before the middle of the eighteenth century. For an excellent reading of Herder's reception of Scottish music which emphasises that Herder's coinage of the term Volkslied exclusively referred to poetry (and not music), see Gelbart, The Invention of "Folk" Music, 102-110. Herder's enthusiasm for Ossian and his translations of Macpherson did not countenance any awareness of the Irish origins of Ossianic lore. 
identity at one and the same time..$^{10}$ By the mid-1780s, when the Irish antiquarian Joseph Cooper Walker published his Historical Memoirs of the Irish Bards (1786) in which he declared that "Irish music is the voice of nature and will be heard", this conflict was at its most acute. Charles Burney, the foremost music historian of his day, reviewed the Irish Bards and poured scorn on the "Milesian claims" which Walker dared to make on behalf of ancient Irish music. ${ }^{11}$ Meanwhile, the renewed interest in Irish antiquities (partly occasioned by the influence of Herder himself) would lead to the Belfast Harp Festival of 1792, in which the remnants of harp music were patiently transcribed and arranged for pianoforte by Edward Bunting, who published his General Collection of the Ancient Irish Music in 1796/7.12 It was this publication, rather than Walker's Irish Bards, which consolidated the powerful (albeit essentially misleading) idea that for Irish music to be authentic it had to be remote, ancient and distinct from the currency of English and European music of the present age. It isn't difficult to understand how this insistence chimed with the reception of Celtic literature on the continent (especially in the full romantic glare of Herderian notions of purity, nobility and natural origin), but the mystique and romance of Celticism in Europe must be distinguished, nevertheless, from the political and cultural significance of music in Ireland. The mutation from Celtic to Gaelic at the end of the eighteenth century was hastened not only by a corresponding mutation from cultural to political ferment, but also by the rapid disappearance of the Irish language itself, a steep decline which lent urgency to the preservation of Irish culture, almost as a static and inanimate object, as against its assimilation into a modern Irish political and social context. In these circumstances, the Irish language, either as a presence or an absence, would come to represent not a "lost" civilization (as in Europe) but a radically suppressed one. This meant (among much else) that the bardic ideal represented by Gaelic civilization would be carried forward, if at all, through the medium of English. It also meant that when Thomas Moore began to compose and publish his Irish Melodies in 1808, his express intention was to "translate" what he took to be the meaning of Irish music ("the tone of sorrow and dispossession", as he put it) into verse. ${ }^{13}$ Between the actual music of the antiquarian collections and the interpretation of this music in Moore's Melodies lies an auditory imagination intent on translation. But it is a translation from Irish music into English verse, with the rider that

${ }^{10}$ See O'Halloran, “Irish Recreations of the Gaelic Past: the Challenge of Macpherson's Ossian”, 69-95.

${ }^{11}$ Burney's scathing review of Walker appeared in The Edinburgh Review, December, 1787, 425-439. His principal objections to Walker's antiquarianism lay in the author's claims for a vanished (and vanquished) musical civilization, claims buttressed by an unmistakable indictment of English rule in Ireland. This repudiation is in striking contrast to Burney's enthusiasm not only for Macpherson, but for the universal "modality" of "primitive" music, including Scottish music (in contrast to the civilizing principles of tonality). See Gelbart, The Invention of "Folk" Music, 12-128.

${ }^{12}$ For an account of Edward Bunting's role in the preservation, dissemination and publication of Irish music, see Moloney, "Bunting, Edward", 139-140.

${ }^{13}$ See Kelly, Bard of Erin. The Life of Thomas Moore, 152-190, for an account of the genesis, development and transmission of Moore's Irish Melodies. The "tone of sorrow and dispossession" which Moore associated with Irish music is a phrase taken from the author's preface to the first number of the Melodies (Dublin: James and William Power, 1808). 
this verse should convey the author's romantic conception of the original music intact. What is more, the Irish Melodies explicitly depend on the original music to justify and animate the linguistic import which they contain. The seam of imagery in the Melodies which relies on the commonplace projection of the bard and his harp as a metaphor of the dispossessed imagination (with its dim roots in classical antiquity and the "Aeolian harp" of Greek poetry) entails a unique address upon music itself, not as a metaphorical presence, but as a sounding form. ${ }^{14}$ In this reliance, Moore is not only at odds with his romantic contemporaries in Germany, but with the Irish literary revival which came after him as well. In this reliance, too, Moore's achievement is radically distinct from the whole tradition of art song in Europe which he nevertheless influenced in significant measure. Put plainly, Moore's is a unique achievement: in writing verse which seeks to interpret pre-existing music, he reverses the normative process in Europe, by which music seeks to interpret pre-existing verse. Moore's own verse stands behind French and German music in ways which compare to Goethe's presence in Schubert (to name just one germane instance), but the Irish Melodies represent an act of imagination for which there is no useful parallel before or after their appearance, and certainly not in Germany. In Moore's influential but exceptional case, the order of creation is prima la musica, poi le parole, a plain reversal of the circumstances which governed the reception of Irish and Scottish poetry in Germany. And Moore's own reception in Europe was primarily as a poet: "Where in Germany, even today, would you find three literary heroes to set beside Lord Byron, Moore and Scott?," Goethe inquired in $1824 .{ }^{15}$ Moore spoke to German romanticism not as a musician, but as a poet. His domestic reception was otherwise, because the music to which he set his verse remained in circulation. Even when Moore stood accused of having distorted its natural estate in favour of his own poetics, its essential "antiquity" was not in doubt. The music became pre-existent and immutable, an ancient borrowing to aid verbal sentiment. It is this state of affairs which led Thomas Davis to remark in 1848 that "it is not necessary for a writer of our songs to be a musician". ${ }^{16}$

\section{The musical sovereignty of German culture in relation to Bardendichtung}

When I observe that Ireland's contribution to European romanticism was through the agency of poetry rather than music, I am merely restoring Moore's presence in German and French musical affairs (particularly with regard to Schumann and Berlioz). This manifested itself half a century after Macpherson and Scotland had animated the bardic cult of German literary romanticism, above all in Denis, Herder and Goethe, with its rich musical afterlife in Löwe and Schubert. ${ }^{17}$ One does wonder, nevertheless, about how much

${ }^{14}$ See White, "The Lyre of Apollo: Thomas Moore and the Irish Harp", forthcoming.

${ }^{15}$ Cited in Boyd, Goethe's Knowledge of English Literature, 265.

${ }^{16}$ Thomas Davis (1814-1845) was a political journalist and poet and a major figure in the Young Ireland movement. See O'Donoghue, ed., Essays Literary and Historical by Thomas, 274. See also O'Connor, "Davis, Thomas Osborne", 283-284.

${ }^{17}$ For a richly detailed survey of the musical response to Macpherson and Scottish music in 
Scottish music the German poets and idealists of the late eighteenth and early nineteenth centuries actually knew. The same question could be more practicably extended to those composers who responded to the cult of Ossian, either through German translations of the original or as a result of Goethe's influence (notably in The Sorrows of Young Werther). ${ }^{18}$ As Gelbart has observed:

German professional composers and their supporters around the turn of the nineteenth century represented a second and completely different group of outsiders shaping an idea of folk music for themselves. Tradition and nation (as "nature") were for them sources of genius that they needed to tap into for their own work. While the folk collectors were censuring the very idea of professional composers touching national music [...] the modern professionals clearly needed to define folk music in a way that was rightfully theirs to access. They sought to translate into "art" the universality and genius that were attributed to tradition - and thus to conceive folk music in aesthetic rather than historical terms. ${ }^{19}$

It is this conception - folk music at one remove, folk music as an aesthetic construct rather than as an historic resource - which finally distinguishes the German musical response to the cult of Ossian from Scottish and Irish antiquarianism. This is not to underrate the impact of Macpherson's publications on the short-lived but immensely influential development of bardic poetry in German-speaking lands: not later than 1768, when Michael Denis began to translate Macpherson in Vienna (working from the Italian translations of Melchiore Cesarotti), the process of Germanizing Ossian was well underway. ${ }^{20}$ Rudolf Tombo, whose Ossian in Germany (1901) surveys the assimilation of Macpherson's Gaelic hero into the bloodstream of the Bardendichtung itself, has this to say about the influence which Macpherson exerted on Friedrich Gottlieb Klopstock (1724-1803), a pioneer of German poetry emancipated from the formal tyranny of French verse:

The dim forms of Ossian's heroes, the misty atmosphere of the Highlands in which they lived, were well calculated to cast a spell over [Klopstock]. There is certain mistiness in Klopstock's great epic (Messiah) that reminds one of the shadowy atmosphere in which the heroes of the Ossianic epics are enveloped. More than one passage in the Messiah conveys the impression of representing little more than rhetorical bombast. Macpherson was a kindred spirit.

This was, however, by no means all that Ossian held out to him. He saw something in Ossian that he seized upon even more eagerly — too eagerly, in fact — namely, he regarded Ossian as a German.

In an epistle to Denis, dated Copenhagen, Jan. 6, 1767, he says: "I beg you not to make me wait for your translation of Ossian. He is an excellent Bard!!” And in another letter to the

Germany, see McCue, "Scottish Song, Lyric Poetry and the Romantic Composer", 39-48. McCue emphasises the elaborate and highly worked musical textures devised by Schubert in response to Macpherson's original poems (in German translation), and contrasts these with the strophic simplicity of texture and design envisaged by Herder and Goethe.

${ }^{18}$ Goethe translated several of the Ossian lyrics in this novel (1774).

${ }^{19}$ Gelbart, The Invention of "Folk" Music, 196.

${ }^{20}$ Denis published a German translation of Macpherson's Fragments of Ancient Poetry in 1769. 
same, dated Bernstorff, Sept. 8, 1767, he writes: “Ossian's works are true masterpieces! If we could discover such a bard! The desire to do so is an ardent wish." ${ }^{21}$

It is hard not to read these comments as an adumbration of Goethe's enthusiasm for Thomas Moore, over half a century afterwards. But there can be little doubt that in "regarding Ossian as a German," Klopstock and his bardic adherents reconfigured the great, natural otherness of the Ossian myth to answer the profound yearning for a mythology of their own. In the new synthesis of Ossianic lore and German verse which the bardic poets achieved is a powerful precedent for the synthetic condition of German song, and for Volkstümlichkeit itself. ${ }^{22}$ By 1779 , when Herder writes the preface to the second volume of his folksongs, the distinction between "folk" and "art" music is no longer vested in a contest between nature and artifice, but rather in a progression from the raw materials of "national music" to the high art of the professional composer. The exhilaration and purity of discourse which Macpherson had claimed for his "translations", the evidence for the "sublime" which the Ossian myth itself represented, had been a synthetic creation from the start. No less synthetic was the response of German composers to the "ideal type" of actual folksong. We might even say that just as Klopstock had Germanized Ossian, it was left to Löwe and Schubert (among many others) to invent a modal past from which their Ossianische Gesänge might be derived. ${ }^{23}$ The one composer who did otherwise was Ludwig van Beethoven.

\section{The nature of Beethoven's Irish musical experience}

Barry Cooper's observation that "Beethoven composed more folk song settings than any other genre and that more of them are Irish than any other nationality" is incontrovertible and disingenuous at one and the same time. ${ }^{24}$ It is perfectly valid to draw attention to the 71 settings of Irish melodies which Beethoven arranged for the Scottish publisher George Thomson between 1809 and 1815 (most of these appeared between 1814 and 1816), and to acknowledge the Scottish settings which he published as his op. 108 in 1822, two years before the premiere of the Ninth Symphony in 1824. But as Gelbart remarks, even in the second edition of The New Grove Dictionary of Music and Musicians (2001) “Beethoven's

${ }^{21}$ See Tombo, Ossian in Germany, 83-85.

${ }^{22}$ This term connotes "naturalness" of poetic diction, in radical contrast to the artifice and mannerism of French-inflected verse.

${ }^{23}$ Some of Schubert's Goethe settings (as in "Die Forelle" and "Heidenröslein") undoubtedly echo the "folk song" ideal perpetrated by Herder as a literary concept, but such settings nevertheless engage a degree of artifice (as in the piano figuration and harmonic structure of "Die Forelle") which is wholly unrelated to this ideal.

${ }^{24}$ See Cooper, "Beethoven's Folksong Settings as Sources of Irish Folk Music", 65. More recently, Cooper has acted as advisor to a new recording (and forthcoming edition) of Beethoven's Irish song settings released as Beethoven's Irish Songs by the DIT Conservatory of Music and Drama in 2014. See www.beethovensirishsongs.ie (accessed 17 November 2015). The project was directed by Dr Kerry Houston, Head of Academic Studies at the Conservatory. 
large corpus of folk song settings comes at the very bottom of the works list - even below the spurious works!" 25 Many of them are ohne Opuszahl, a highly significant designation. ${ }^{26}$ "Meanwhile", Gelbart continues, "the Ninth Symphony has gone on to become the anthem of the European Union, surely one more assertion that it represents both universal folk brotherhood and cultural capital as intellectual achievement". ${ }^{27}$ But whether or not we regard them as routine commissions or examples of serious engagement, these settings remain beneath the radar of organic idealism, not least because the reception of the "universal" element in the Ode to Joy, by contrast, reconfigures the folk ideal as ideal, as originary and unrelated to any empirical reliance on folksong. This idealism carries forward through Brahms and Wagner and into the twentieth century. The least we can argue, in light of this reception history, is that Beethoven's engagement with Irish folk song (even the term itself is problematic, given the sources from which his arrangements were derived) had little or no impact on the organic idealism of German music, even where this was inflected by universals of modality and a self-conscious address upon the "other" of national music. ${ }^{28}$ Indeed, the synonymous understanding of "national" and "natural" promoted by Herder entailed a far greater preference for the "unheard" melodies of the imagination (as in Keats's ode) than for the "primitive" remnants of the folk collections. This is not to deny the importance of creating a synthetic "folkishness" in German song (Volkstümlichkeit again), a preoccupation which would endure as late as Brahms, but it is to affirm that as Beethoven and Mendelssohn surely realized, the actual encounter with Irish music produced far less satisfactory results than did the enchantments of Ossian and the Homeric style of Macpherson's forgeries. This was partly because the condition of Irish and Scottish music, as it made its way into collections published from the late eighteenth century onwards, unmistakably represented a repertory of dance tunes of very recent provenance, and partly because the modern German Bards (not least Goethe himself) had invented a strain of poetry inspired by Ossian but fully formed in its own right. If Klopstock regarded Ossian as German, it is small wonder that German composers preferred the "unheard melody" of Gaelic mythology to the fixed formulas of peasant musical culture. But even if this were not the case, the results produced in Beethoven's song settings attest an exceptional and ultimately discounted (if not superfluous) utterance, at least to judge by their immediate reception history and subsequent neglect.

This is an argument which finds support in recent scholarship, at least insofar as this

${ }^{25}$ Gelbart, The Invention of "Folk Music", 224.

${ }^{26}$ The absence of opus numbers for these settings silently attests, in my view, their relative unimportance in the wider context of Beethoven's compositional achievement, to say nothing of its reception history. This would scarcely matter were it not for the fact that Beethoven's musical imagination is (at best) a remote presence in these arrangements.

${ }^{27}$ Gelbart, The Invention of "Folk Music", 224. Neither "cultural capital" nor "intellectual achievements" are concepts easily summoned, however, by Beethoven's adventures in Irish music.

${ }^{28}$ There is no doubt that Beethoven set airs communicated to him by Thomson through the agency of various collectors (including Bunting): in this regard, the settings do not represent original composition of any kind. By contrast, Schubert's response to Gaelic poetry (in translation) was newly conceived. 
facilitates a comparison between Moore's settings and the Beethoven collections published between 1814 and 1816. ${ }^{29}$ A new recording of the Beethoven settings (and a forthcoming edition by Barry Cooper) likewise encourages a more determined consideration of the differences between Moore's enterprise and the routine commissions accomplished by Beethoven..$^{30}$ Moore (and his collaborators, John Stevenson and Henry Rowley Bishop) and Beethoven (aided by the Scottish publisher George Thomson) find common ground in the arrangement of Irish airs for voice and piano (notwithstanding Beethoven's addition of optional parts for other instruments, usually violin and cello), even if Beethoven seems to have been frequently unaware of the character of the airs which Thomson sent him. It was Thomson, in fact, who added "suitable" lyrics to Beethoven's arrangements, many of which he commissioned from English and Scottish poets of the day. This is a sequence not lost on Cooper, who suggests in turn that "it is not essential to use the texts Thomson chose [...] Beethoven designed most of his settings so that, as with hymn tunes, almost any texts with the right metre and character could be used, including, of course, texts in Irish". ${ }^{31}$ Even if we were to set aside a musical comparison between Moore and Beethoven (which in any case would almost certainly founder on the difference between Beethoven's overwrought figurations and the comparative simplicity of the Moore-Stevenson accompaniments, notwithstanding a degree of continuity between them), Moore's verse promotes intractable difficulties on its own account. This is simply because of the unitary force of Moore's poetic, achieved in direct response to the airs themselves. The quality of "translation", as from music into poetry, and more particularly from Irish music into English verse, remains paramount throughout the Irish Melodies. It is scarcely necessary to add that this quality is wholly absent from Beethoven's settings; nor do we need to overplay the radical contrast that obtains between the organic force of Beethoven's compositional technique in 1814 and the constricted condition of these arrangements written for a ready market. It is, however, germane to this comparison to recognize anew the fundamental difference between a musical constituency of interest such as Beethoven's, in which words inspired music (rather than the other way around), and Moore's constituency, in which music (uniquely) inspired a sequence of poetry destined to exert a profound influence on the subsequent development of Irish letters, without reference to the music which gave it life. Ossian was the stuff of romantic legend, but Moore's poetry - albeit indirectly- spoke to the political culture of his own day. So, too, did Moore's reading of Irish music as a semantic code of dispossession and loss.

A very different afterlife awaited the cult of Ossian in Germany after its primary manifestation as a trope of romantic reawakening in Herder and Goethe. The bardic ideal in German poetry, in other words, produced a musical correlative which was no less

${ }^{29}$ In particular, see Hunt, Sources and Style in Moore's Irish Melodies (in press). Although this book does not enterprise a detailed comparison between Beethoven's settings and Moore's songs, its sensitive (and extremely detailed) appraisal of John Stevenson's role in the Irish Melodies will be of serious account in any future consideration of Beethoven's approach to Irish music.

${ }^{30}$ See note 24 above for details.

${ }^{31}$ Cooper, "Beethoven's Folksong Settings", 81-82. In this regard, it is noteworthy that the recent Dublin recording of these settings features new texts, many of which are by Moore. 
idealised and organic, notwithstanding a determination to create a synthetic discourse of folk music which had very little to do with the "vulgar trash" that poor Mendelssohn had to endure in Scotland. In this respect, at least, we must distinguish between the national longing for form which animated Herder and the young Goethe in the closing decades of the eighteenth century and the nationalism which radically affected German musical identity after the Congress of Vienna in 1815. In musical terms, this longing was satisfied by a romantic nationalism which celebrated at every turn the organic prowess of German music as a narrative of German musical supremacy which drew as much authority from Zelter, Mendelssohn (and indeed Goethe himself) as it did from Beethoven, Haydn and Mozart.

Even if we leave to one side the inherent chauvinism of much German commentary (especially in relation to French and Italian music), we cannot mistake the consolidating (or colonizing) tendency of German music in its self-reliant absorption of other traditions, national and otherwise. Above all, perhaps, we should not underestimate the acutely political condition of relations between German music and literature in the late eighteenth and early nineteenth centuries. The formative influence of Macpherson in shaping a national identity for German literature (we might even say for literature in German) must finally be distinguished from the very different condition of German music during the same period. Whether addressing mankind through the agency of Schiller in 1824 or romancing the Orient through the agency of Thomas Moore in 1843, composers such as Beethoven and Schumann were in no doubt about the organic primacy of their musical discourse, whatever the dependencies (Irish, Scottish or Indian) of the poetry they set.

\section{Bibliography}

Boyd, James. Goethe's Knowledge of English Literature. Oxford: the Clarendon Press, 1932. Cooper, Barry. "Beethoven's Folksong Settings as Sources of Irish Folk Music". In The Maynooth 1995 International Musicological Conference, Irish Musical Studies 5, edited by Patrick F. Devine and Harry White, 65-81. Dublin: Four Courts Press, 1996.

Dahlhaus, Carl. Between Romanticism and Modernism: Four Studies in Music of the Later Nineteenth Century, translated by Mary Whittall. Berkeley: University of California Press, 1984.

Gelbart, Matthew. The Invention of "Folk Music" and "Art Music". Emerging Categories from Ossian to Wagner. Cambridge: Cambridge University Press, 2007.

Hunt, Una. Sources and Style in Moore's Irish Melodies. Farnham, Surrey: Ashgate Publishing, forthcoming.

Kelly, Ronan. Bard of Erin. The Life of Thomas Moore. Dublin: Penguin Ireland, 2008. McCue, Kirsteen. "Scottish Song, Lyric Poetry and the Romantic Composer". In The Edinburgh Companion to Scottish Romanticism, edited by Murray Pittock, 39-48. Edinburgh: Edinburgh University Press, 2011.

Moloney, Colette, "Bunting, Edward". In The Encyclopaedia of Music in Ireland, edited

by Harry White and Barra Boydell, 139-140. Dublin: University College Dublin Press, 2013.

O’Connor, Maria Patricia. "Davis, Thomas Osborne”. In The Encyclopaedia of Music 
in Ireland, edited by Harry White and Barra Boydell, 283-284. Dublin: University College Dublin Press, 2013.

O'Donoghue, D. J., ed. Essays Literary and Historical by Thomas Davis. Dublin: The Talbot Press, 1914.

Ó Gallchoir, Clíona. "Celtic Ireland and Celtic Scotland: Ossianism and The Wild Irish Girl"'. In Scotland, Ireland and the Romantic Aesthetic, edited by David Duff and Catherine Jones, 114-130. Lewisburg: Bucknell University Press, 2007.

O'Halloran, Clare. "Irish Recreations of the Gaelic Past: the Challenge of Macpherson's Ossian”. Past and Present 124 (1989): 69-95.

Rushton, Julian. "Berlioz and Irlande: from Romance to Mélodie". In The Maynooth International Musicological Conference 1995, Selected Proceedings, Part Two, Irish Musical Studies 5, edited by Patrick F. Devine and Harry White, 224-240. Dublin: Four Courts Press, 1996.

Tombo, Rudolf. Ossian in Germany. New York: Columbia University Press, 1901.

White, Harry. "Review of Matthew Gelbart, The Invention of "Folk" Music and "Art" Music. Emerging Categories from Ossian to Wagner, Cambridge: Cambridge University Press, 2007'. Journal of the Society for Musicology in Ireland 4 (2008-9): 75-77.

White, Harry. "The Lyre of Apollo: Thomas Moore and the Irish Harp". In Harp Studies, edited by Sandra Joyce and Helen Lawlor. Dublin: Four Courts Press, forthcoming. 


\section{MACPHERSON, OSSIAN IN BARDSKI IDEAL \\ NEKAJ IRSKIH MISLI O NEMŠKEM FENOMENU}

\section{Povzetek}

Namen razprave je ponovno raziskati zgodovino idej, v kateri je bil ugled »ljudske glasbe« kot Herderjevega in Goethejevega ideala z miselnostjo nemške romantike v 19. stoletju preoblikovan. Herderjevo navdušenje za Ossianove pesmi Jamesa Macphersona, nekatere izmed njih je v nemščino prevedel Goethe, imamo lahko za izviren in vzoren idealizem, ki je izginil po Beethovnovih uglasbitvah irske tradicionalne glasbe. Kljub njihovemu znatnemu številu Beethovnove uglasbitve niso vplivale na porast glasbenega idealizma, ki je ostal brezbrižen do položaja škotskih in irskih »ljudskih pesmi«, kot se je kazal v prvih desetletjih 19. stoletja. Kontrast med Beethovnovimi uglasbitvami (izdal jih je škotski založnik George Thomson) in Mendelssohnovim prezirom »avtohtone« glasbe prikaže idejno potovanje od »ljudske glasbe« kot koncepta, skoraj soznačnega s poezijo bardov (nem. Bardendichtung) v poznem 18. stoletju, do odkritja in zavrnitve same glasbe kot dejavnega principa $v$ nemški glasbeni miselnosti.

V zgodovini recepcije lahko prepoznamo tri različne faze: (a) nemško jezikovno suverenost $\mathrm{v}$ odnosu do irske in škotske glasbe, (b) glasbeno suverenost nemške kulture $\mathrm{v}$ odnosu do poezije bardov (Bardendichtung) in (c) ostanek Beethovnovega odnosa do irske glasbe, predvsem v okvirih, določenih z zbirko Thomasa Moora Irske melodije v Dublinu in Londonu, ter izkoreninjenost te glasbe kot izraza lokalnega kolorita v Nemčiji. Komentarji »zloglasno, vulgarno, nemelodično«, kot jih je slišal Mendelssohn na turneji po Škotski in Walesu leta 1829 , so bili v izrazitem nasprotju z idealizirano podobo o tej glasbi prejšnje generacije. V tretjem desetletju 19. stoletja je postala »ljudska glasba« kot znanilec narodne zavesti v nasprotju s prevladujočim stanjem v nemški umetnosti. 